\title{
The Dark Side of the Lasem Maritime Industry: Chinese Power in Opium Business in the XIX Century
}

\author{
Siska Nurazizah Lestari, Nara Setya Wiratama \\ Universitas Nusantara PGRI, Kediri \\ Indonesia
}

\begin{abstract}
Some of the issues discussed in this article are the shipyard industry development at Lasem, and revealing the factors of Chinese traders conducted smuggling by sea. This study shows the dark side of the maritime industry found in Lasem mainly related to Chinese power in the opium business, XIX century. These problems analyzes with critical historical methods which consist of four stages, including a) heuristics, seeking and collecting historical sources, both primary and secondary sources; b) source criticism, the process carried out to test the authenticity and credibility of the source; c) interpretations, interpret and compile facts from one another; $d$ ) historiography, the process of rewriting historical events. According to the results, there was a concentration of Chinese residences during the colonial period. Lasem's Chinese settlements (Chinatown) had rapid growth after the

Received:

December 8, 2018

Revised:

December 22, 2018

\section{Accepted:}

January 23, 2019

Corresponding author:

siskahistoria2005@gmail.com migration of Chinese and the Chinese massacre as known as Geger, Pecinan. To maintain its existence, the Chinese in Lasem initiated the opium business, developed in the nineteenth century by sea. The presence of the Lasem River also strengthened this finding, became the lifeblood of economic activity in the past. The Lasem River also connects the hinterland with the coastal area, so it has a negative impact mainly related to the smuggling of opium.
\end{abstract}

Keywords: Chinese; Lasem; Opium.

\section{Introduction}

Lasem was a small city located in the south of Rembang. Since ancient times, Lasem had been called la petit chinois or Small China, because of the many Chinese descants and people living in old Chinese-style houses that had stood for centuries. Formerly the city was a large port city from the time of the small kingdom of Lasem under the Majapahit Kingdom to the Dutch colonial occupation (Adi, 2014: 11-15).

The large number of ports that developed rapidly on the North Coast of Java became the gateway for the export of food from Java to the whole archipelago. The food was then bartered with Indian cloth in Aceh and Malacca, as well as spices from Banda and Maluku. Lasem was also an important part of this commercial activity (Tarling, 1999: 148). Intensive business activities had made many domestic and other traders from outside the archipelago, including China, visit Lasem.

Most of Chinese people who came to Indonesia in general and in the northern coastal areas of Java in particular, came from the provinces of Fukien/Fujian and Kwang Tung. The Lasem Chinese community was estimated to be predominantly from Zhangzhou County, Fujian province, because worship of some glorified figures in the temples followed the worship procedure as in temples in Fujian province (Suliyati, 2009).

Meanwhile, Rembang (including Lasem) in $1815^{1}$ ranked 4th with the largest Chinese population. Rembang's Chinese citizens accounted for $4 \%$ of the total Chinese population who were censored by the British government on Java (at that time under Raffles power). The development of the ethnic Chinese population in Lasem made the settlement complex to develop. Many Chinese people migrated to Java, one of which was Lasem, that were not motivated by fertile land but because they wanted to follow his predecessors who had succeeded in Lasem and built a residential complex in that location. At that time, there were Dutch

${ }^{1}$ The data were collected from Raffles's book, entitled History of Java, 1: 62, No. II "Table Exhibiting the population of Java and Madura, according to the British Government in the Year 1815”, which was reprocessed by Peter Carey (Carey, 1984 in the Indonesian Journal: 1-47). 
regulations, which prohibited Chinese people ${ }^{2}$ from owning agricultural land, forcing them to enter into the business of commerce. Thus, the Chinese ethics in trading opium made the Chinese ethnicity in Lasem grow very rich in the nineteenth century. They had magnificent houses and ships that supported their trading activities so they could grow rapidly (Pratiwo, 2003: 150). Based on the background, the formulation of these study questions are: 1) What was the development of the shipyard industry in Lasem?; 2) Why did ethnic Chinese conduct smuggling through the sea? This study revealed the dark side of the maritime industry found in Lasem, especially in relation to Chinese power in the opium business in XIX century. The method used in this study are heuristics, source criticism, interpretation and historiography.

\section{Development of Lasem Maritime Industry}

The northern part of Lasem's geographical area was a coastal area, the eastern side was a mountainous area and the central part has topography in the form of a plain. Lasem was like the North Coast cities of Java which were strong areas with its maritime industry in the past. This was inseparable from the role of the Lasem River which supported industrial activities. At the mouth of the Lasem River, there was a port that was frequently used to land small ships connected by road, connecting the area to other areas.

In the past, the Lasem River became the lifeblood of commercial activity in the area. The river also connected inland areas to the coastal areas. The port/pier at the mouth of the Lasem River functioned as an inter-port and made people and goods go to and from the Lasem area and surrounding areas as well as from other areas (other islands), that would go to Lasem and its surroundings. In addition, the port connecting the Lasem River also connected the Kiringan River which was in the side of Lasem. The Port of Lasem, in the past, was a landing place for merchant ships.

Ports in Lasem could be classified as ports. The estuary of the Kirigan River and Bonang-Binangun Bay occupied waters that were protected against waves and wind for the anchoring of ships, filling in logistics of shipping supplies, repair or maintenance of ships. Lasem had been known as a port city since the 16th century and was a group of big cities along the North Coast of Java (Elliot, 2013). An area could be established as a Bandar/port having criteria in the form of river estuaries with adequate water depth. In addition, the port was one that was equipped with buildings for cargo services such as docks, ship moorings, storage warehouses with all their needs (Balar Research Team, 2011: 30). Its position as a port city made Lasem develop in the maritime industry.

The existence of the Lasem River also formed the morphological design of Lasem City. In the past, the Lasem River became a busy transportation route, making the local people build settlements along the river path. Buildings that are still firmly standing up to now along the Lasem River can be found in Dasun, Babagan, Soditan, and Karangturi. The maritime industry in Lasem was able to attract migrants to develop settlements in the vicinity. Although the interior area was the center of government in the era of Bhre Lasem in power and its successors, the pulse of economic activity was concentrated on the port area. The area around the port attracted Chinese people who later established Chinatowns. Chinatown areas were close to ports and markets, while indigenous people preferred to live around the port, the square, and along the Lasem River upstream (Veth, 1882: 793-794).

Indigenous people in Lasem who lived around the port earned income as fishermen. The maritime industry in Lasem was not only concerned with transportation and commerce, but Lasem also had a very prominent shipbuilding manufacturer. As found in Rembang and Banjar, there were traces of shipyards to make or repair large ships. Ship creation in Lasem used raw materials from teak forests (Poesponegoro et al., 2008: 51). Over time, the shipyard industry suffered from collapse due to the high cost of producing and repairing fishing vessels and other small vessels. The small-scale shipbuilding industries were managed by indigenous people. The higher production costs were caused by the scarcity of wood needed to repair and make ships. Small-scale shipyard industry players in Lasem could not transport raw materials from other regions efficiently, resulting in increased production costs. Nevertheless, shipyard industry workers could continue to work with other work diversifications related to woodcraft. They mostly became carpenters who remained in the Lasem area but had to leave their homes every year to work to Surabaya and Kediri regions (Veth, 1882: 793-794).

Several references said that the shipyard industries in Lasem that developed long before the presence of VOC in the archipelago were small and medium shipbuilding industries. However, Poesponegoro explained that shipyards and ports in Lasem were equivalent to port cities such as Rembang and Juana. The types of ships

\footnotetext{
${ }^{2}$ The colonial government called it de Chinezen.
} 
produced at the shipyards included the Gonting ship (Pramono, 2005: 113), ${ }^{3}$ and Jung ship, which had capacity ranging from 50 to 60 tons (Poesponegoro, et al., 2008: 51).

Lasem had indeed triumphed in trading and shipbuilding, but the decline in prosperity in the region in the nineteenth century caused ship owners and managers, as well as some fishermen who were experienced in navigating the Lasem and surrounding seas to turn to the Opium smuggling business. In the 1870s and 1880s, their success in smuggling opium made the Lasem region nicknamed the "funnel of opium" in Java (Rush, 2012: 78).

The shipyard business managed by the indigenous people in Lasem had indeed faded in the nineteenth century. It was later taken over by the European private shipyard industries, some of which were the Nering Bugle company, Dunlop and followed by the P. Berendsen company (early XX century) in Dasun. The shallow water conditions before the estuary of the Lasem river were obstacles that had to be faced if you wanted to build a shipyard south of the inlet of the Lasem River. European shipyard businesspeople knew that the wood raw materials still had affordable prices, only limited supply was constrained. Therefore, efficiency could be obtained by building steam power-sawing facilities and other equipment to maximize materials and processing time. However, a woodcarving of parts and objects were made of metal exclusively processed by hand (Veth, 1882: 793-794). In the nineteenth century, shipyard products in Lasem had competitors from shipyards in Rembang (Sutherland, 1973: 132). Large shipyards at that time indicated that Lasem was a strategic area (Poesponegoro, et al., 2008: 51).

As a maritime city, Lasem had become a strong ship production center, both warships and merchant ships from the Majapahit era to the VOC period. The ships were produced on the banks of the Lasem River (Babagan River) which were the lifeblood of the Lasem community. The Lasem shipbuilding industries in the past were only of historical importance which left the foundations (Elliot, 2013).

In shipbuilding in the past, wood-raw materials to make ships were obtained from the interior of Lasem. Teak wood used for the raw materials of the ship was washed away following the flow of Lasem (Babagan) river towards the shipbuilding dock. Shallow waters along Lasem Coast and shifting sand dune at the river mouth made Port of Lasem no longer used as interport. This also affected the Chinese community settlement patterns along the Lasem river. Changing environmental conditions led the Lasem community to switch to use of land routes (Veth, 1882: 793-794). Until the 1860s, the remaining shipyards in Dasun (Lasem) Village belonged only to Dutch individuals (Figure 1). Travel record of Radèn Mas Arjä Poerwä Lelänä explained that there were four official shipyards built in Lasem, one of which belonged to Europeans from Surabaya (Putte, 1868: 23). The shipyard had no contact with the Chinatown. It was caused by the protection of the Chinese people due to the trauma of the yellow war that took place in the seventeenth century.

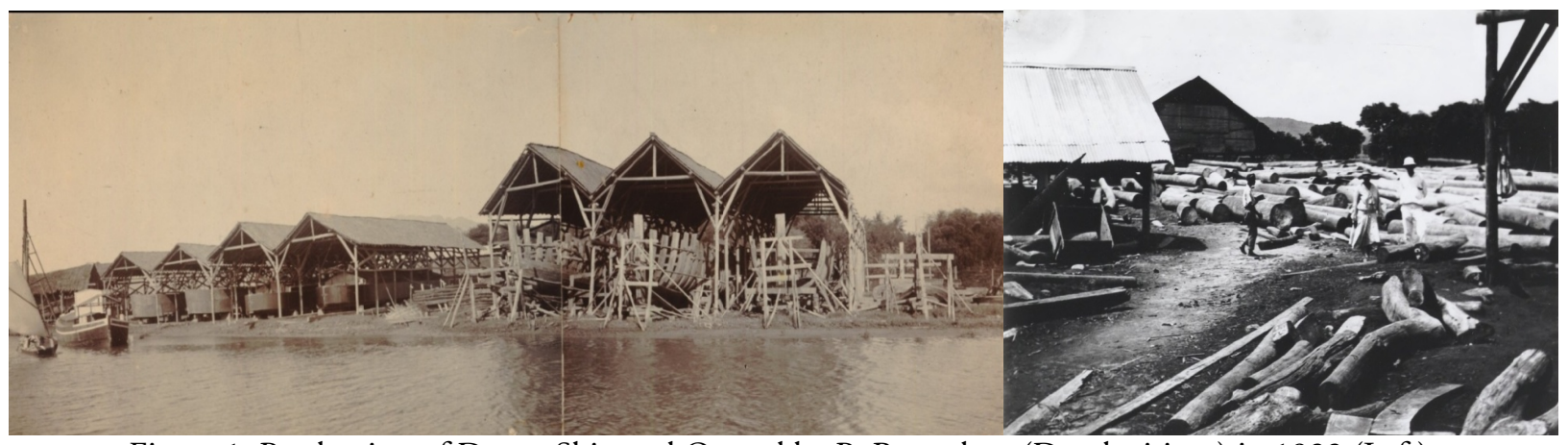

Figure 1. Production of Dasun Shipyard Owned by P. Berendsen (Dutch citizen) in 1922 (Left); Supply of Woods for P. Berendsen Shipyard at Lasem River in Dasun in 1922 (Right) Source: KITLV Collection.

The construction of Lasem's shipyard was not supported by adequate raw materials, such as wood, copper, and metal. Shipyards, one of which was privately owned by Europeans, had difficulty in getting wood and copper, the situation can be seen at Figure 2. Therefore, shipyards could only repair ships (Keyzer, 1867: 24-25). In fact, European shipyards located on the Lasem River allowed large ships to be constructed in Lasem. The constructed ships were also diverse, such as the Java Jung ship and Dutch steamers. The products of these ships were used for Dutch expeditions and shipping. The reason why the Dutch established shipyards was that the Dutch needed ships with low production costs. This was due to high commercial activity (Willink, 1848:

Gonting ship was a ship made without a deck or floor of the ship, size of around 13-20 meters, and used as an inter-regional transportation mode. 
511-512). However, there were a number of specific reasons why the shipyard was established in Lasem. First, to oversee the activities of Chinese people in Pecinan (Chinatown), Lasem. Secondly, preventing opium smuggling through the Lasem river. Even so, the smuggling of opium in Lasem was still widespread, even facilitated by one of the descendants of the owner of the P. Berendsen shipyard. ${ }^{4}$

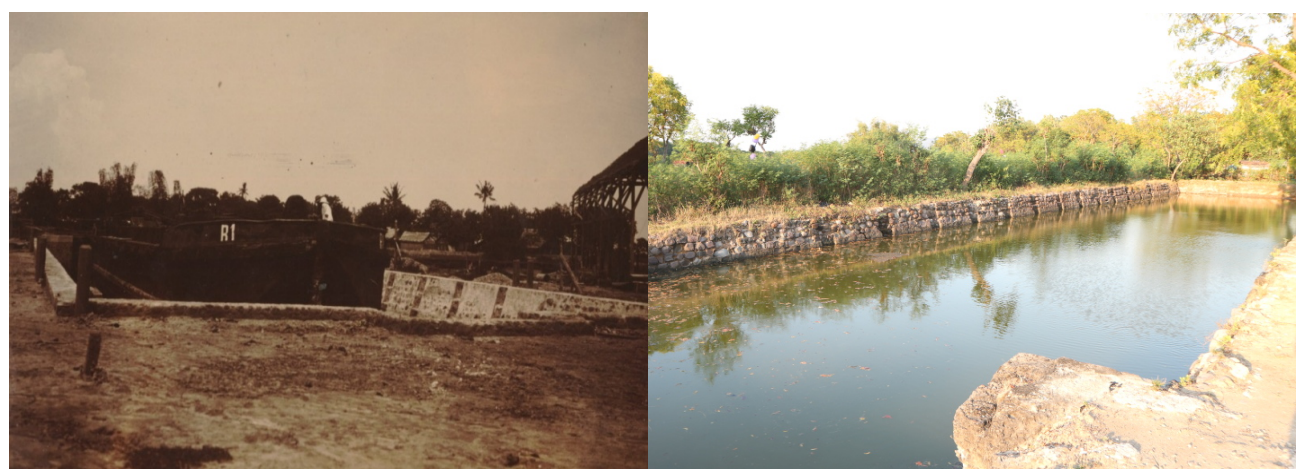

Figure 2. Part of the Berendsen Shipyard at Lasem River in 1922 (Left); Current Situation in 2018. Source: KITLV \& Author Documentation.

\section{Chinese Power in Opium Smuggling at Lasem}

The circulation of opium in the Lasem region had a long history and links with the distribution of opium from the South Asian region. At the beginning of the seventeenth century, two northern European charter trading companies competed to dominate the prestigious Indian Ocean trade routes. In the 1650s, the Dutch trading company in the Archipelago (Vereenigde Oostindische Compagnie, VOC) had succeeded in pushing the British Trading Company in the East Indies out of Southeast Asia. The VOC bought opium produced in Bihar and West Bengal and Patna from Indian traders and transported it to Southeast Asia. When exactly did opium arrive in the Dutch East Indies, no sources were explaining in detail about it. Some informants only documented the circulation of opium in India after Britain held control of Bengal in 1765. David Owen once interpreted that the monopoly of Mughal opium had been carried out sometime after the death of the great Mughal emperor in the early seventeenth century. In the monopoly, there was the involvement of a group of Patna traders in opium commerce in Patna at the end of the 18th century from Mughal rule. Seeing expanding production rapidly, the British East India Company (EIC) was relatively slow to participate in this trade. EIC sent its first opium shipment in 1708. While the VOC first built trade octopuses in Southeast Asia. The Indian opium industry developed due to the Bengali province which was rich in opium products. When he was governor of Bengal in 1772, Hastings began reforming the opium industry regarding the administration of corrupting and inefficient companies. The reform created a system of contracts that were complying with the monopoly rights of opium sold every year. Opium produced by Bengal farmers was then sold and auctioned to private traders who brought it to China and Southeast Asia (mainly to Singapore and Java) (Wright, 2013).

Opium production for the global market then developed into a home industry in many places in the Southeast Asia region. Local farmers and traders had developed opium products that had similar qualities to products from West Asia. The thesis stating that opium originated from East Incha carried by people in Europe to Southeast Asia was untrue because there was no evidence to substantiate it, including evidence about how to process and package the opium. At the beginning of the eighteenth century, the great demand for "Bengal" opium was in the global market. The opium was compacted in spherical form and packaged in crates for export. Bengal opium began to be traded in Aceh and China in 1704. The practice of buying and selling was suspected of being the first established practice of buying and selling. The Dutch effort to expand the opium trade during the seventeenth century was able to develop a broader market, especially in Southeast Asia (Hui Kian Kwee, 2006: 169).

The Netherlands was the first country that made opium a "small" yet expensive commodity in the Southeast Asian region. It then made opium a promising form of capital. The Netherlands changed the way opium was used to boost its popularity. The Dutch also had a role in bringing the habit of smoking opium to China. The beginning of the change in using opium was adapted from Java. However, it was not clear whether the Dutch, Javanese or Chinese people first mixed opium with tobacco in their use for cigarettes. The method of using opium for smoking with tobacco was explained in the Kaempferopada Report in 1689 (Hui Kian

\footnotetext{
${ }^{4}$ In accordance with the collective memory of the Lasem community, especially around Dasun Village.
} 
Kwee, 2006: 169).The use of opium by the Javanese was different from the general, because they mixed it with tobacco which was dissolved in water so that it made the head dizzy and felt like rotating harder. The tool used to suck was called waterpijp or water pipe (bong). Indigenous people sucked opium using Bedhutan (Nurhajarini, et al., 2015). In Java, opium packages were usually sold in the form of thin lumps mixed with certain types of tobacco. The packages were sold to some passing customers. Opium became a commodity in the East Indies which was very profitable, even in Batavia. Kaempfero in his report explained that users of smuggled opium (including Lasem) would not get opium other than those carried by ships from Batavia from Bengal and Coromandel. Opium commonly consumed by Javanese people (including in the Lasem region and beyond) was estimated to be approximately 350 ringgit (Hui Kian Kwee, 2006: 169). Details of the actors (sellers and users) are represented in Figure 3 and 4.

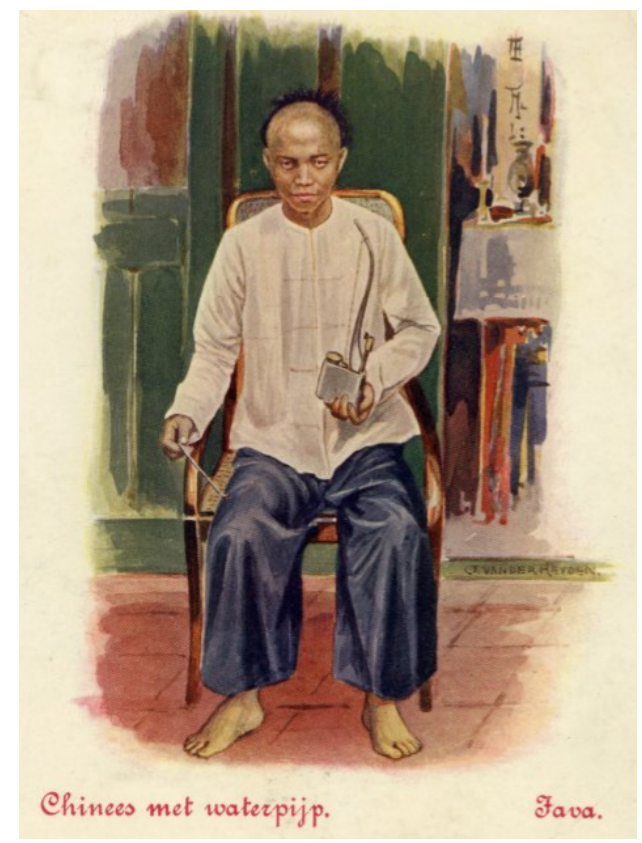

Figure 3. Illustration of Chinese Using Opium Bong (Waterpijp) Source: Chineses met waterpijp. Java, in 1900, KITLV.

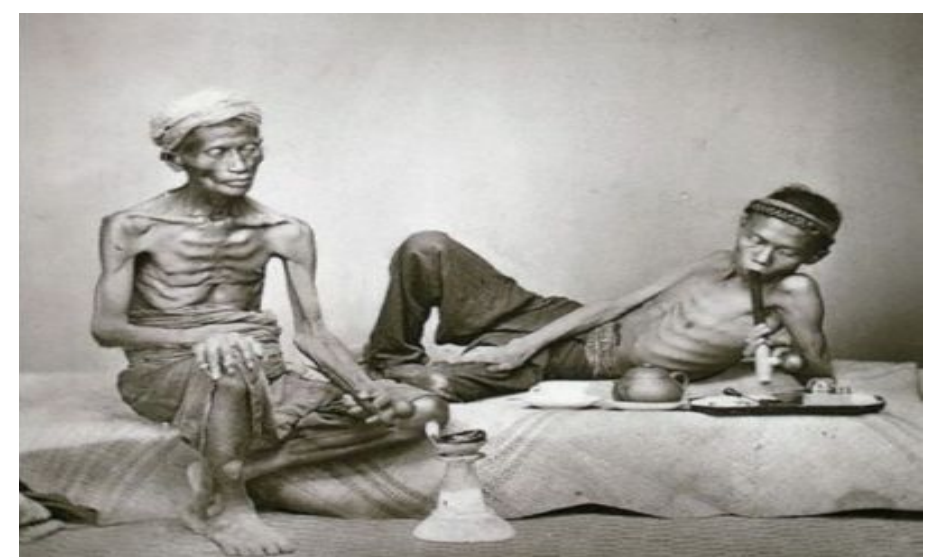

Figure 4. Addicting people sucked opium using bedhutan in Java (1880s) Source: Tropen Museum Collection.

Edkin's study claimed that the consumption of opium was sucked from the brasal in Taiwan in the early eighteenth century. The habit to consume opium was carried out by educated young people who did not have full time jobs. They usually gathered together at night to smoke opium. The report by John Crawfurd, which originated in the early nineteenth century, agreed with what Kaempfero argued that some Javanese peoples who smoked opium learned the habit from Chinese people. The social phenomenon found in 1800 showed the habit of smoking opium as something that was typical of Chinese community. The point of view of some Europeans and natives considered consumption of opium as a social disease and endangering themselves (Trocki, 2012: 34-35). 
Indigenous people were known to be very addicted due to the habit of consuming opium in only a relatively short time. They had been taught on how to use it by foreign Easterners when they did business. However, the widespread consumption of opium which damaged the social structure of the Javanese society was a result of the monopoly of the trade in opium by Europeans, as well as smuggling done by Chinese people. Most people in the archipelago always smoked opium, did not eat or chew opium, such as Turks, and other Asians (Trocki, 2012: 34-35).

The distribution of opium in Java had to be done by indigenous people who knew how to reach consumers. The Dutch also began to cultivate opium by employing opium farmers. The Dutch introduced the opiumregie policy, and its domination of the opium market was more incomparable than the VOC or the previous period. At the time, not only Java and Madura became the area where opiumregie was implemented. Opiumregie's policy aimed at minimizing or even eradicating opium consumption; in other words, there was no place to compete in the sale of opium. The companies similar to NHM also stated that opiumregie had the rights to monopolize the opium trade, not only in Java and Madura but also throughout the archipelago (Derks, 2012: 319).

The Dutch authorities made various efforts to reduce the crime of smuggling opium, especially in the Lasem region and beyond. The businessmen of Chinese opium smuggling were able to pay for the East Dutch Indies apparatus at high prices. Therefore, they easily obtained the smuggled opium to supplement their opium reserves purchased from the government. Most smuggled opium went to Java via the coastline between JeparaRembang (including Lasem region) from Singapore, while the rest went through Bali (originating from China). The smuggled opium had more than the number of legally imported opium products. Chinese opium businessmen took advantage of what they paid to the government. The profit depended on the sales of black market opium which valued one tenth of the cost of connecting legal opium. Chinese opium businessmen paid the government because the Netherlands provided protection related to handling contraband opium. The protection was carried out by manipulating anti-smuggling catching activities, so that Chinese opium businessmen could specifically inhibit the activities of their competitors. Opium counterfeiters were the elites of the Chinese business community (Fernando and Bulbeck, 1992: 77).

Notes on the smuggling of opium carried out in Lasem were clearly recorded on the Mas Arjä Poerwä Lelänä Radèn's ${ }^{6}$ journey in the Java region in 1867 . When Radèn Mas Arjä Poerwä Lelänä stopped in the developing area after traveling from Gresik and Tuban, he was fascinated by the splendor of Chinatown in Lasem which was about eight paal from the city. Radèn Mas Arjä Poerwä Lelänä liked the region because it was very quiet and was occupied by many Chinese conglomerates. He was informed by local residents that the life of wealthy people in the Chinatown area of Lasem was supported by the sale of smuggled opium to several other regions even to the Surakarta region (Delftsche Courant, August 27, 1867).

The supply of opium in Lasem was so easy, because the Chinatown of Lasem was close to the sea and far from Rembang. The mode of smuggling was not carried out by anchoring large ships, considering that the ships had difficulty to anchor in Lasem because the pier was not so large and had a shallow (mound) rock. One of the paths taken was loading and unloading activity in the middle of the sea along Lasem waters by Chinese ships $^{8}$ sailing through Singapore. In addition to carrying commodities in the form of goods imported from China, the ships also carried opium from Singapore. Loading and unloading activity was carried out at night after the boats were in the Lasem water region. Opium products on large ships were then moved to fishing boats. The fishing ships carrying opium landed in a region farther away from Chinatown, and some fell in Chinatown. Most fishing ship landing sites were on the coast that stretched in the Lasem area. Opium smugglers were Javanese and Chinese laborers, who were promised to get money, but were not in direct contact with the mastermind behind the smuggling. When the workers were arrested by the police, taken to prison and sentenced, the arrested workers could not appoint or provide information regarding the mastermind behind the smuggling or the name of the owner of the smuggled opium (Delftsche Courant, 27th August 1867).

According to some informants, the smugglers who smuggled the opium were Javanese-Chinese or poor indigenous people. Likewise, it was right for the introduction of contraband opium to other regions in Java.

${ }^{5}$ Opiumregie did not only regulate monopoly, but also it regulated special packaging and standardization of opium plants. The opium was given a special sign or seal so that cheating could be detected. Hans Derks, History of Opium Problem: The Assault on the East, Ca. 1600 - 1950 (Leiden: Brill, 2012), p. 336.

${ }^{6}$ Based on the work of M.A. Candranegara (Regent of Demak in the 1860s), Arya Purwa Lelana was an elite Javanese figure who traveled to see the condition of Java (M.A. Candranegara, Cariyos Bab Lampah-Lampahipun Raden Mas Arya Purwa Lelana,. 1867, N/A).

${ }^{7} 1$ paal $=1,507$ meters or almost equivalent to 1 mill.

${ }^{8}$ Also known as the Wangkang ship. 
Smuggled opium business syndicates had a dominant strategy, making it difficult to arrest, even though Dutch police often conducted raids on smuggled opium expeditions. Expedition couriers or coolies detained by police and tried in court never knew who the real owner of the contraband opium was. The identity of the smuggled opium businessman was challenging to reveal because the network of coolies or couriers with syndicates of opium business was arranged so neatly. During the detention period of couriers or coolie laborers, opium owners would take care of their food needs by sending envoys who also kept the identity of the opium owner confidential. When the couriers and coolies were free, they would receive a prize if they could maintain the status of the opium owner secret (Bonneff, 1986: 186).

Every village head received bribes in the form of money or opium when the smuggled opium was sent to Surakarta. The gift was not to help secure the smuggling of opium, but to allow the opium expedition to pass (road money). Therefore, the government felt very difficult to prevent this smuggling. Smuggled opium traders were not afraid of spending more money in large quantities, because the profits from selling opium by depositing road money were higher (Bonneff, 1986: 186).

In the Lasem region, evidence of smuggling of opium in the past can still be seen today. One of them was the Tong brothers, Tong Kei and Tong Dei residences. The two brothers smuggled large amounts of opium into a house in front of the Lasem River. Tong Dei and Tong Kei made a hole to smuggle opium right on the river in front of the $\mathrm{Cu}$ Ang Kiong Temple. The (Dutch) government conducted which carried out by loading and unloading activities, given the logistical needs of the $\mathrm{Cu}$ Ang Kiong temple were quite large. The smuggling was carried out in the mid-XIX century period. Tong Dei and Tong Kei were one of the biggest syndicate of opium smugglers at the time. They had large numbers of porters and couriers.'

Cave or holes that were used as smuggling roads were approximately 1.5 meters. Opium was smuggled through the northern part of the Tong brothers' house. Opium was then stored in the back of the house. Distribution was carried out by using a ox cart, horse cart or pikul (137 lbs). The opium was stacked with other commodities which were local products of Lasem. The network of smuggling and distribution of opium by Tong brothers was elegant, so it was challenging to be sniffed by the Dutch government officials. ${ }^{10}$

In its development, the house used for smuggling was later purchased by the Chinese Kapitan in Lasem named Lim King Siok. ${ }^{11}$ The house was then kept away from the Lasem River because the Netherlands sniffed the smuggling of opium. Settlements in the Chinatown area of Lasem, especially in the Dasun region, initially had a short distance to the Lasem (Babagan) river. The river was then minimized and made to move away at a distance of about $50 \mathrm{M}$ from the house with a reason to reduce the chances of smuggling opium done by the Chinese of Lasem. Houses in Chinatown, especially around the Lasem River, were established quite magnificent and surrounded by high fences (Knapp, 2013). Most of the large houses in the Chinatown of Lasem were owned by wealthy Chinese people from the opium business (Keyzer, 1867: 24-25).

In 1851, the Dutch Indies Government applied strict control of Chinese people suspected of smuggling opium and hiding their colleagues from the census. This event occurred after the disclosure of a large number of criminal cases of smuggling opium in Java. The considerable smuggling occurred in Surabaya, Rembang (including Lasem) and Pasuruan. The Dutch East Indies government also gave heavy penalties to smugglers, as well as expelling illegal migrants. The Dutch East Indies government felt very difficult to uncover smuggling because it was carried out by people with highly confidential and neat syndicates. Syndicates of smuggling opium were the objects of study by cynologists. The Dutch East Indies government sent documents in Chinese script about the businesses to Hoffmann in Leiden, who at that time was the only European who knew Chinese. Hoffmann published two articles with translation and analysis of the document. The results of the investigation concluded that the syndicates were dangerous to the Dutch authorities in the Dutch East Indies. Hoffmann also confirmed that the businesses were related to secret societies in China (Kuiper, 2017: 867).

The policy of controlling opium did not make opium smugglers feel the deterrent. Syndicates of smuggling opium were even more difficult to arrest. It was evident from the rise of smuggling after the 1860s. In 1886, it was explained that the number of illegal clandestine opium products in Rembang were found. Lurah (village head) Pempirak received bribes of half a pikul of opium. ${ }^{12}$ Meanwhile, the Tjandoe Lasem officer received IU opıum arums. I ne wedono Ngulaan assistant also took hundreds of opium packages. Some of the

\footnotetext{
${ }^{9}$ It was as told by the descendant of Tong brothers from Singapore in Si Hwi Djian (Interview with Gandor Sugiharto).

${ }^{10}$ Documents regarding the deaths of the Tong brothers were discovered by Singaporean.

${ }^{11}$ The cause of the death of the Tong brothers was not known exactly, however, a written source brought to Singapore explained that the tomb of the Tong brothers was close together in a cemetery in the Jepuro (Juwana) area. Interview with Si Hwi Djian (Interview with Gandor Sugiharto).

${ }^{12}$ Estimated at $50 \mathrm{Kg}$.
} 
packages were found by authorities in Rembang with a total of 20 drums. It indicated that smuggling in Rembang and Lasem was very alarming (Soerabaijasch Handelsblad, $10^{\text {th }}$ September 1886).

Seeing the rampant of opium smuggling by Chinese people in the Lasem region and its surroundings, the Netherlands was increasingly strict in issuing strategies. The strategy was to reduce smuggling, namely the abolition of monopoly, and the import ban and consumption of opium. Another alternative was that the government would maintain the supply of opium itself, and take advantage of it. Besides, the Netherlands also had a strategy to suppress opium prices as cheaply as possible, which the government gave to official sellers (opium patcher) but still maintained a monopoly. To remain profitable, the Netherlands substantially increased rent. In this way, the Dutch were convinced that tenants or authorized sellers (opium patchers) would not be interested in illegally importing opium. High demand for opium caused patchers to smuggle opium. It made the strategy carried out by the Dutch unable to reduce smuggling of opium (Willink, 1848: 511-512).

Reduction of opium smuggling was also pursued by way of opium monopolization established in Java. Planted commodities had to be better in Sulawesi, Sumatra, and other regions. The Dutch bought opium from Bengal and Smyrna every year at a price of $f 600,000$. The monopolization of opium plantations would certainly benefit because it reduced shipment wages. At the same time, the Netherlands also strictly prohibited the import of foreign opium (Willink, 1848: 511-512).

The Chinese opium businessmen in Lasem did take all opportunities in the opium business. They also wanted to spend large sums of money only to become official tenants or sellers of opium (opium patcher). As happened in 1897, a Chinese captain at Lasem named Liem Hing Pimau paid for the lease of the rights to sell opium in Japara from 1898 to 1900 . Liem Hing Pi rented $f$ 40,010,- every month. The rental price was more expensive, at $f$ 7,000 per month than the price paid by Liem Hing Pi before. Liem Hing Pi became the only Lasem person who was able to pay dearly to control the legal opium trade in the Jepara and surrounding areas (Bataviaasch Nieuwsblad, 11 October 1897).

Lasem opium businessmen were able to compete with other opium businessmen, especially in Central Java. Lasem opium businessmen were able to pay more for the official rent or sale of opium than other businessmen; for example, opium patcher in Kedu and Jepara residents. The opium patcher at Kedu resident fell on a high bidder from Semarang named Boh Biauw Tjoan at a price of $f 28,040$,- per month, for a period of three years. ${ }^{13}$ This price was still lower than to Jepara. The rental price (opium patcher) in Java reached $f$ 33,010 per month, for a period of three years. The highest bidder for opium patcher in Jepara was the Chinese captain named Liem King Poen ${ }^{14}$ from Lasem (Java-bode: Nieuws, Handels-en Advertentieblad voor Nederlandsch-Indie, 20 September 1897). The owners of the opium or tenant license (opium patcher) tried their best to benefit from what they had paid. Therefore, it was not uncommon for them to smuggle opium to get more profits.

The richest Chinese conglomerates in Central Java in the 1890s resided in Semarang. They had interests in the opium business, not only in Semarang but also throughout Java (including Lasem). Most of the clandestine opium that entered through the "opium funnel" on the north coast of Java from Juwana to the Lasem area was then sorted in Semarang. They hoarded the opium, and sold it when the price of opium rose. Some of them were part of the trading partnership of Kian Gwan controlled by Oei Tjie Sien and his son Oei Tiong Ham. This partnership developed in the opium business in Central and East Java in the years 890-1891 (Cohen, 2006: 90).

Opium smuggling was indeed a difficult thing to eradicate. A. C. Pe Rooda (the highest authority in Ambtenaar in the Rembang region) stated that the Ambtenaar experienced difficulties in eradicating the circulation and smuggling of opium in Lasem. By the twentieth century, the mode of smuggling opium was not through the river that led to Chinese settlements, but through the coast around the village of Dessa Cikalan, Binangun. One of them was as revealed in 1889, the Dutch Ambtenaar found as many as 13 opiates (crates or drums) in a resident's house called Djasmadie, Cikalan Village, Binangun (Soerabaijasch Handelsblad, $13^{\text {th }}$ November 1889).

The smuggling of opium in the area near the coast was also revealed in 1903. The smuggling was accidentally revealed by local indigenous people. The person was busy plowing his field close to the coast, suddenly the plow found a hard object. After the land around the object was excavated, the native found 14 petroleum drums filled with opium. Not far from the field, a ship originating from Singapore was found, found in a damaged state. The colonial government confiscated the opium and investigated ship ownership (Soerabaijasch Handelsblad, 7 April 1903).

\footnotetext{
${ }^{13}$ The guarantor was: the former Chinese captain in Semarang, Beh Kwat Kong; and Chinese lieutenant in Ambarawa, Kwee Siauw Ging.

${ }^{14}$ The guarantor of the lease was Liem King Tie, a Chinese lieutenant in Blora and Lie Hong Kie from Pati.
} 
Another case of smuggling in the Lasem area was successfully published in the Soerabaijasch Handelsblad newspaper. The newspaper reported that the Rembang Regent had followed up on reports of opium smuggling on the coast near Lasem with evidence of 14 sacks of opium originating from Singapore. The opium sacks weighed $350 \mathrm{kati}$, equivalent to $200 \mathrm{~kg}$. If calculated, the smuggling would result in a Dutch loss of $f 10,500$. This loss did not include losses in the distribution area which, if estimated, reached many $f$ 106,400. A large amount of smuggling of opium that was not revealed caused the Dutch to be unable to calculate losses in total. Several times, the smuggling of opium by Chinese people was successfully carried out (Soerabaijasch Handelsblad, 4 April 1903). The smuggling was very neat, opium was hidden, covered with blades of bamboo (Bataviaasch Nieuwsblad, 2 April 1903).

The Dutch apparatus finally focused on massive smuggling in North Java. The Dutch East Indies police patrol was deployed. One of them was implementing several steamers combing the North Coast of Java. They patrolled along Rembang Coast to East Lasem by using spotlights at night. Although the extensive efforts were made intensively, the government could not find smuggling of opium in large scale. Several possibilities caused the police patrol not to produce maximum results. First, opium smugglers knew the police operation route. Second, smuggling was carried out in stages with a small amount of opium. Smugglers were more accessible to hide small amounts of contraband on the coast. Third, smugglers used unlit (light) ships so that they could get away from police patrols.

The opium smuggling was carried out quickly at Lasem. As soon as smugglers carried their opium on land, the transit to the coastal and Chinatown settlements of Lasem did not face much trouble. Some Chinese timber portals were suspected of helping in the process of smuggling opium. The houses of the Chinese timber dealers had a location to store opium, disguised as other goods (Soerabaijasch Handelsblad, 4 April 1903).

The term Opium funnel for the Lasem region was inseparable from the strength of the maritime industry Lasem for centuries. Massive smuggling of opium was inseparable from people's knowledge of the maritime industry, especially in the shipping sector. The rampant opium smuggling business displaced the dimming of the maritime industry in Lasem in Lasem. Fishing ships were modified in such a way as to transport opium from the middle of the sea with a knowledge system owned by the local community. Besides, the Dresden P shipyard industry that developed in the twentieth century also had a stake in smuggling opium. The successor of the Dresden shipyard business was working with residents to smuggle opium which also involved timber dealers for ship production.

\section{Conclusions}

The shipyard business managed by the indigenous people in Lasem increasingly faded in the nineteenth century. It was later taken over by the European individual shipyard industries, some of which were the Nering Bugle company, Dunlop and followed by the P. Berendsen company (early XX century) in Dasun. The shallow water conditions before the estuary of the Lasem river were obstacles that had to be faced if you wanted to build a shipyard in the south of the estuary of the Lasem River. European shipyard businessmen knew that the wood-raw materials still had affordable prices, only limited supply was constrained. Therefore, efficiency could be made by building steam power-sawing facilities and other equipments to maximize materials and processing time. However, wood carvings and objects made of metal were exclusively processed by hand.

Lasem once triumphed in trade and shipbuilding, but the decline in prosperity in the region in the nineteenth century caused the owners and managers of ships, as well as some fishermen who experienced in navigating Lasem and its surrounding sea, to turn to the Opium smuggling business. Opium made Lasem's area nicknamed the Javanese "opium funnel." The supply of opium in Lasem was very easy, because the Chinatown of Lasem was close to the sea and far from Rembang. The mode of smuggling was not carried out by anchoring large ships, considering that the ships had difficulty to anchor in Lasem because the pier was not so large and had a shallow (mound) reef. One of the taken paths was loading and unloading activity in the middle of the sea along Lasem waters by Chinese ships sailing through Singapore. In addition to carrying commodities in the form of goods imported from China, the ships also carried opium from Singapore.

\section{References}

Bataviaasch Nieuwsblad, 11 October 1897.

Bataviaasch Nieuwsblad, 2 April 1903.

Candranegara I. (Raden Mas Adipati Arya), Marcel Bonneff. Pérégrinations Javanaises: Les voyages de R.M.A. Purwa Lelana: Une vision de Java au 19e siècle, c.1860-1875. Paris: Les Editions de la MSH, 1986. 
Cohen, Matthew Isaac. The Komedie Stamboel: Popular Theater in Colonial Indonesia, 1891-1903. Ohio University Press, 2006.

Delftsche Courant, 27 August 1867.

Derks, Hans. History of the Opium Problem: The Assault on the East, ca. 1600 - 1950. Leiden: Brill, 2012.

Elliot, I.M.C. Batik: Fabled Cloth of Java. Tuttle Publishing, 2013.

Fernando, M. R., David Bulbeck. Chinese Economic Activity in Netherlands India: Selected Translations from the Dutch. Institute of Southeast Asian, 1992.

Hui Kian Kwee. The Political Economy of Java's Northeast Coast, C. 1740-1800: Elite Synergy. Leiden: Brill, 2006.

Java-bode: Nieuws, Handels-en Advertentieblad voor Nederlandsch-Indie, 20 September 1897.

Keyzer, Salomo. Radèn Mas Arjä Poerwä Lenänä. S'gravenhage: N/A, 1867.

Knapp, R. Chinese Houses of Southeast Asia: The Eclectic Architecture of Sojourners and Settlers. North Clarendon: Tuttle Publlishing, 2013.

Nurhajarini, Dwi Ratna, Ernawati Purwaningsih, Indra Fibiona Akulturasi Lintas Zaman di Lasem: Perspektif Sejarah dan Budaya Kurun Niaga-Sekarang. Yogyakarta: BPNB DIY, 2015.

Poesponegoro, Marwati Djoened \& Nugroho Notosusanto. Sejarah Nasional Indonesia Jilid IV. Jakarta: Balai Pustaka, 1993.

Pramono, Djoko. Budaya Bahari. Jakarta: Gramedia Pustaka Utama, 2005.

Raffles, T. S. History of Java. London: AMS Press, 1983.

Rush, J. R.. Candu Tempoe Doeloe: Pemerintah, Pengedar dan Pecandu, 1860-1910. Jakarta: Komunitas Bambu, 2012.

Soerabaijasch Handelsblad, 10 September 1886.

Soerabaijasch Handelsblad, 13 November 1889.

Soerabaijasch Handelsblad, 4 April 1903.

Soerabaijasch Handelsblad, 7 April 1903.

Suliyati, T. "Melacak Jejak Budaya Cina Di Lasem", dalam Seminar Nasional, Menyusur Sungai Meretas Sejarah Cina di Lasem, 5 Desember 2009.

Sutherland, H. "Notes on Java's Regent Families: Part 1". Journal Indonesia 16 Oktober 1973.

Tarling, Nicholas. "Political Structures in the Nineteenth and Early Twentieth Centuries". In The Cambridge of Southeast Asia Vol. Three, From 1800 to the 1930. Cambridge: Cambridge University Press, 1999.

Trocki, Carl. Opium, Empire and the Global Political Economy: A Study of the Asian Opium Trade 17501950. London: Routledge, 2012.

Veth, P. J. Java Geographisch, Ethnologisch, Historisch. Harlem: BOHN, 1882.

Willink, Tjeenk. Tijdschrift voor Staathuishoudkunde en Statistiek, Volume 4.Te Zwolle, 1848.

Wright, A. Opium and Empire in Southeast Asia: Regulating Consumption in British Burma. London: Springer, 2013. 